\title{
Review on Catalytic Cleavage of C-C Inter-unit Linkages in Lignin Model Compounds: Towards Lignin Depolymerisation
}

\author{
Susana Guadix-Montero ${ }^{1} \cdot$ Meenakshisundaram Sankar $^{1}$
}

Published online: 20 March 2018

(c) The Author(s) 2018

\begin{abstract}
Lignin depolymerisation has received considerable attention recently due to the pressing need to find sustainable alternatives to fossil fuel feedstock to produce chemicals and fuels. Two types of interunit linkages ( $\mathrm{C}-\mathrm{C}$ and $\mathrm{C}-\mathrm{O}$ linkages) link several aromatic units in the structure of lignin. Between these two inter-unit linkages, the bond energies of $\mathrm{C}-\mathrm{C}$ linkages are higher than that of $\mathrm{C}-\mathrm{O}$ linkages, making them harder to break. However, for an efficient lignin depolymerisation, both types of inter-unit linkages have to be broken. This is more relevant because of the fact that many delignification processes tend to result in the formation of additional $\mathrm{C}-\mathrm{C}$ inter-unit bonds. Here we review the strategies reported for the cleavage of $\mathrm{C}-\mathrm{C}$ inter-unit linkages in lignin model compounds and lignin. Although a number of articles are available on the cleavage of $\mathrm{C}-\mathrm{O}$ inter-unit linkages, reports on the selective cleavage of $\mathrm{C}-\mathrm{C}$ inter-unit linkages are relatively less. Oxidative cleavage, hydrogenolysis, two-step redox-neutral process, microwave assisted cleavage, biocatalytic and photocatalytic methods have been reported for the breaking of $\mathrm{C}-\mathrm{C}$ inter-unit linkages in lignin. Here we review all these methods in detail, focused only on the breaking of $\mathrm{C}-\mathrm{C}$ linkages. The objective of this review is to motivate researchers to design new strategies to break this strong $\mathrm{C}-\mathrm{C}$ inter-unit bonds to valorise lignins, technical lignins in particular.
\end{abstract}

Keywords $\mathrm{C}-\mathrm{C}$ bond cleavage $\cdot$ Lignin valorisation $\cdot$ Catalytic depolymerisation $\cdot$ Lignin model compounds $\cdot$ Technical lignins

\section{Introduction}

\subsection{Biorefineries and Lignin Valorisation}

The greatest challenge our society faces is the increased demand for energy and commodity chemicals because of population growth along with the increasing demand from emerging large economies [1]. This scenario is further complicated by the depletion of conventional fossil fuel based feedstock to produce them, the greenhouse effect and consequent climate changes [2]. There is a pressing demand to address the chemical and energy security issues without compromising the environment. One of the proposed alternatives for achieving this is to use green and sustainable alternatives to the conventional feedstock for producing commodity chemicals and fuels. The fuel versus food debate

Meenakshisundaram Sankar

sankar@cardiff.ac.uk

1 Cardiff Catalysis Institute, School of Chemistry, Cardiff University, Cardiff CF10 3AT, UK for the 1st generation biofuels led to the development of 2 nd generation biofuels where, lignocellulosic biomass (or waste biomass) that does not compete with food crops, is used as the feedstock to produce chemicals and fuels [3-5].

Integrated conversion of all the components of lignocellulosic biomass (cellulose, hemicellulose and lignin) in a biorefinery, analogous to a petroleum refinery, to value-added products has been proposed by the International Energy Agency (IEA) to make them economically viable and sustainable [6]. Cellulose is a semi-crystalline homopolysaccharide comprised of unbranched D-glucose (anhydroglucose) units linked at the first and fourth carbon atoms through $\beta$-glycosidic bonds ( $\beta-1,4$ glycosidic bonds) whereas hemicellulose is an amorphous polysaccharide branched with short lateral chains consisting of various different sugars [7]. Lignin, the third component of lignocellulosic biomass, is found in all vascular plants, and is, after cellulose, the most abundant carbon source on earth [8]. It is a naturally amorphous polymer that gives plants their structural strength and shape. Lignin contains highly functionalised aromatic units that makes them a potential sustainable 
feedstock to produce aromatics. It fills the space between the hemicellulose and cellulose, making up the final lignocellulose structure, offering strength through cross-linkages with the carbohydrate polymers (Fig. 1) [7]. Until now, valorisation of both polysaccharides cellulose and hemicellulose have been extensively studied and successfully practised in the industrial production of biofuel (bioethanol, biohydrogen and biogas) [9] and bio-based chemicals and material (such as biopolymers) [10-13].

However, in most of these processes the residual lignin is often burnt as a low grade fuel for power generation or steam production or used as low value products such as dispersing, binding or emulsifying agents, phenolic resins, carbon fibres, wood panel products, automotive brakes and epoxy resins [7, 14]. Lignin is of particular interest because it contains several highly functionalised aromatic moieties. It is the only large volume renewable source of aromatics or platform chemicals [BTX (benzene, toluene and xylene), phenols, and aliphatic fractions (C1-3)]. Bulk chemicals can be produced from these sustainably produced BTX without changing the current processes and technologies $[7,13$,

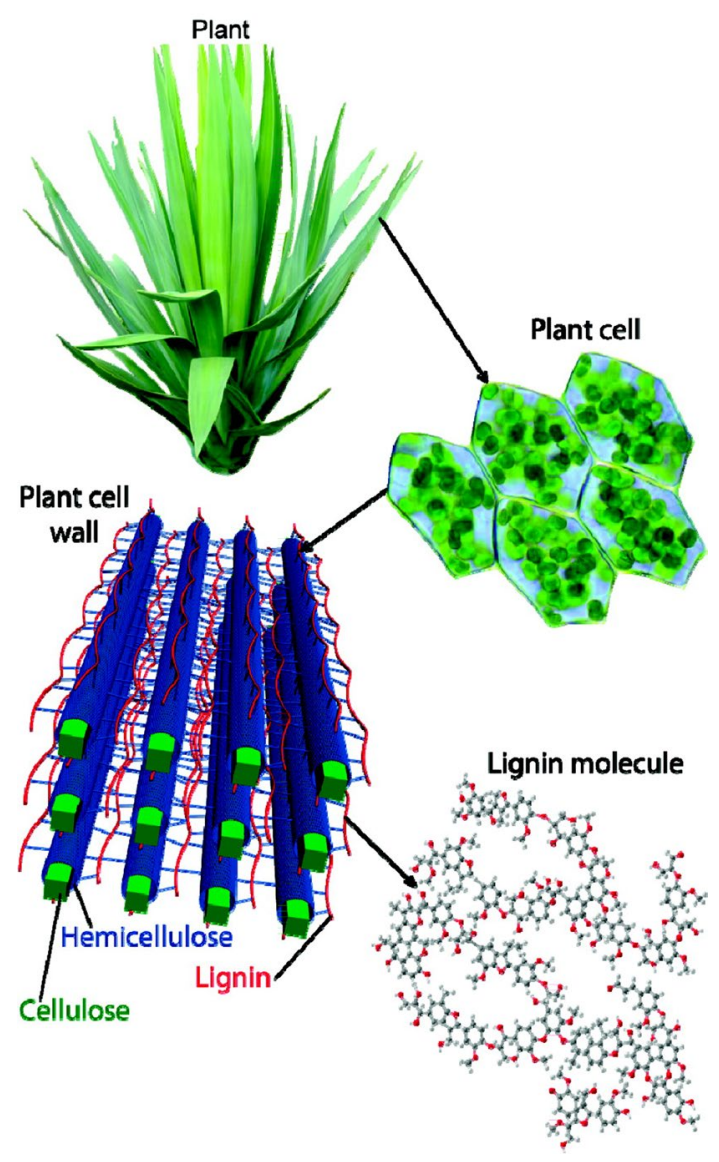

Fig. 1 Representation of the location of lignin in a plant. (Reproduced with permission from reference [7]. Copyright 2010, American Chemical Society)
15]. Economically, converting lignin into fully deoxygenated BTX may not be highly desirable because in certain processes BTX are again oxidised. Hence strategies to valorise lignin, that can preserve the aromatic rings and functionalities present have to be developed. The resultant small aromatic molecules can be used in existing or new routes to produce base chemicals [16].

Lignin consists of several aromatic sub-units: p-hydroxyphenyl type $(\mathrm{H})$, guaiacyl type $(\mathrm{G})$ and syringyl type (S) and they are the result of the polymerization of three types of phenylpropane units that are considered to be the primary building blocks of lignin and are called as monolignols [17]. The monolignols differs from each other in the number of methoxy groups attached to the aromatic ring (none, one or two methoxy groups in the p-coumaryl, coniferyl and synapyl alcohol respectively) (Fig. 2) [18, 19]. The monolignol ratios depend on the type of biomass [18]. In general, hardwood lignin contains mainly $\mathrm{G}$ and $\mathrm{S}$ units and traces of $\mathrm{H}$ units, whereas softwood lignin contains $\mathrm{G}$ units predominantly with very low $\mathrm{H}$ units, and in the case of grass based lignin nearly equal amounts of $\mathrm{G}$ and $\mathrm{S}$ units are found with very less $\mathrm{H}$ units. Compared to hardwood and softwood lignins, grass lignins contain more $\mathrm{H}$ units $[7,17,20]$. For any given lignin sample, the H:G:S ratio can be calculated using wet chemical methods such as acidolysis, nitrobenzene oxidation (NBO), permanganate oxidation, cupric oxide and thioacidolysis [21-23] or spectroscopic techniques such as FT-IR [24] or 2D-NMR [25, 26]. For example, a method for the quantitative analyses of lignin samples was reported by Kline et al. using their normalized Fourier Transform Infra-Red (FTIR) spectra [24]. They assigned the peaks at 1327 and $1267 \mathrm{~cm}^{-1}$ to $\mathrm{G}$ units, the peaks at 1223 and $1123 \mathrm{~cm}^{-1}$ to $\mathrm{S}$ units and the

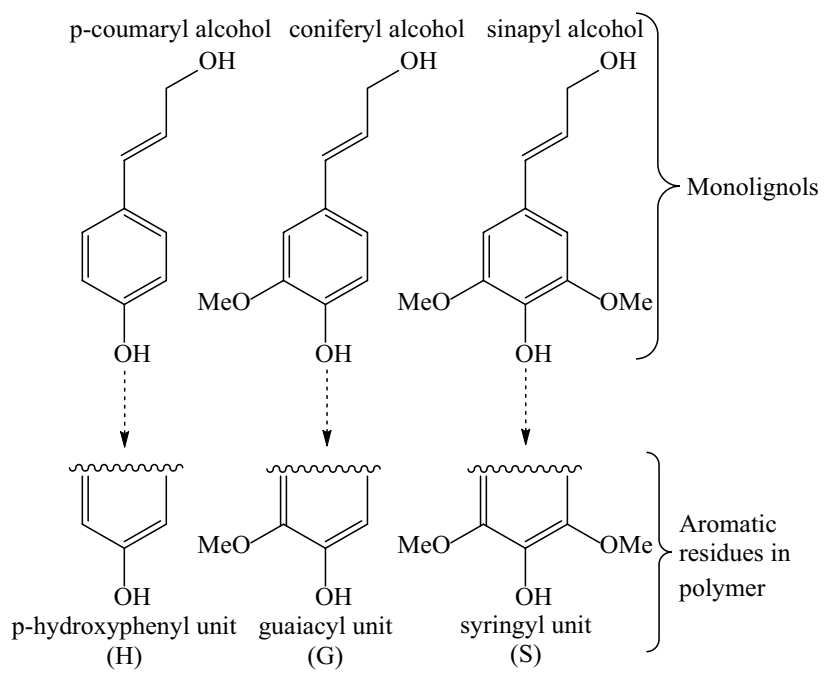

Fig. 2 Monolignol structures and their corresponding residues in lignin polymers. (Adapted from reference [17]) 
$1167 \mathrm{~cm}^{-1}$ peak to $\mathrm{H}$ units [24]. S/G molar ratios can also be semi-quantitatively estimated by Heteronuclear Single Quantum Coherence (HSQC) 2D-NMR spectroscopy [25, 26].

The diversity in lignin structures is not only because of the difference in the ratio of monolignols, but also because of the way in which these monolignols are covalently linked with each other, called inter-unit linkages. These inter-unit linkages are a combination of $\mathrm{C}-\mathrm{O}$ and $\mathrm{C}-\mathrm{C}$ inter-unit linkages $[7,17,27]$. Typical $\mathrm{C}-\mathrm{O}$ and $\mathrm{C}-\mathrm{C}$ interunit linkages, present in softwood lignin, are highlighted in Fig. 3. It is crucial to have a fairly good understanding on the relative strengths of these inter-unit linkages in order to design methodologies to break them.

Huang et al. used density functional theory (DFT) calculations on 63 representative lignin model compounds to predict the bond dissociation energies (BDE) of different types of inter-unit linkages present in lignin [29]. Table 1 contains the BDE data along with the common names and structures of different lignin model compounds having different inter-unit linkages. This table further contains the abundance of each linkage for different lignocellulosic biomass (softwood, hardwood and grass). $\mathrm{C}_{5}-\mathrm{C}_{5^{\prime}}$, having a $\mathrm{BDE}$ around $115-118 \mathrm{kcal} / \mathrm{mol}$, is the strongest of all inter-unit linkages. All $\mathrm{C}-\mathrm{C}$ inter-unit linkages are stronger than $\mathrm{C}-\mathrm{O}$ linkages making them more challenging to break [18].

\subsection{Native Lignins}

In natural or native lignins, as it is present in the raw plant biomass, two-thirds or more of the total inter-unit linkages are $\mathrm{C}-\mathrm{O}$ linkages, especially $(\beta-\mathrm{O}-4)$ ether bonds, while the rest are $\mathrm{C}-\mathrm{C}$ inter-unit linages [20]. As mentioned previously, the native structure of lignin varies from plant to plant and in some cases within the same plant, it differs from one part of the plant to the other. It is important to highlight that it has not yet been possible to isolate the real native lignin from plant tissues since the structure always modifies during the lignin isolation process [30]. Using advanced NMR techniques the structures of complex native lignins, in whole cell wall, have been studied in great detail [31]. Another way to study the structure of native lignins is by careful chemical degradation techniques such as thioacidolysis or from milled wood lignin (MWL), which is usually considered to be more or less representative of native lignin $[32,33]$. Efforts are currently being made to separate native lignins from biomass with minimal structural changes $[18,34]$. It has also been
Fig. 3 Typical inter-unit linkages present in softwood lignin. (Reproduced with permission from reference [28]. Copyright 2012, Elsevier)

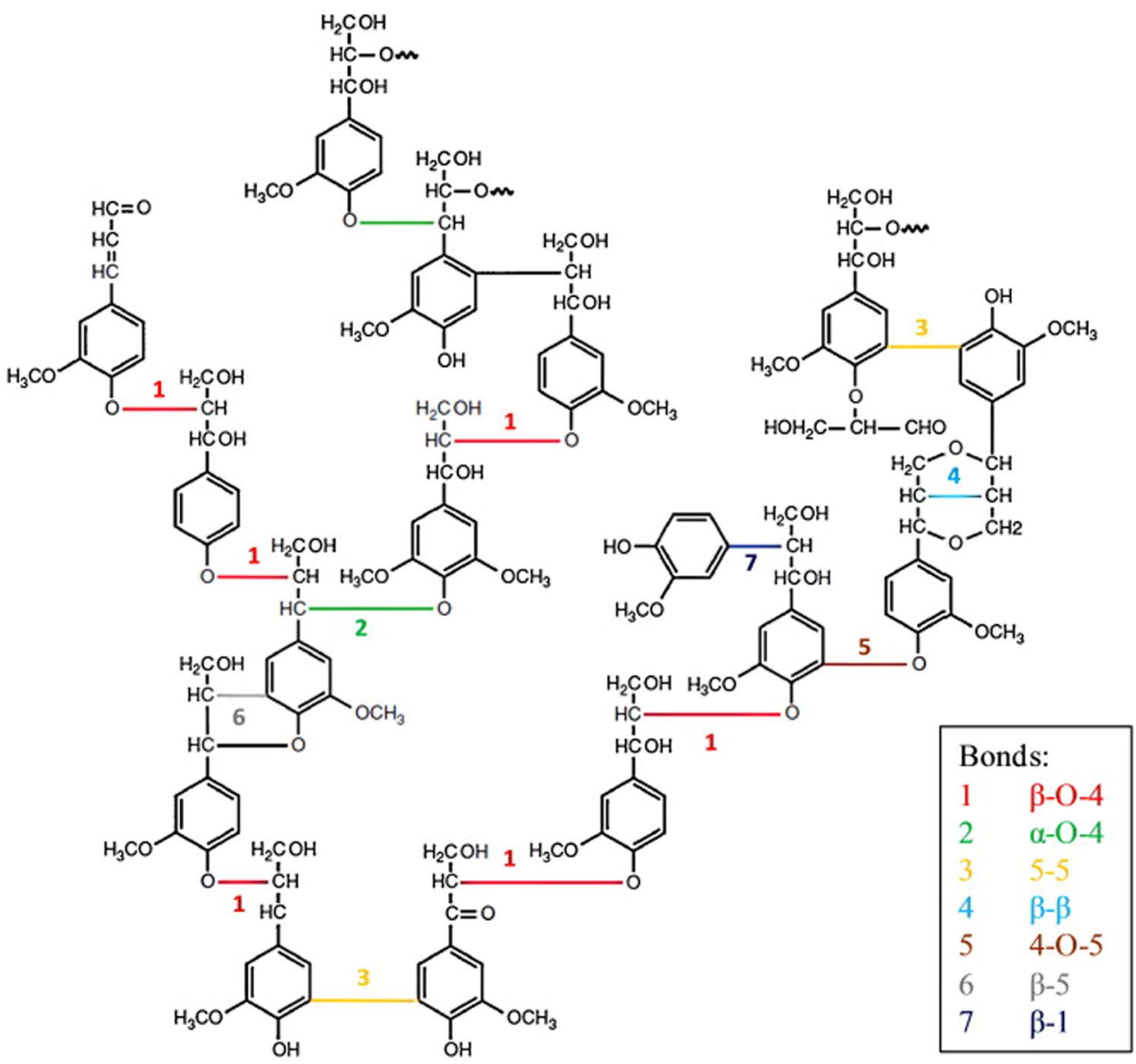


Table 1 List of lignin model compounds representing various inter-unit linkages, their structure, abundance and bond dissociation energies (Adapted from reference [18])

\begin{tabular}{|c|c|c|c|c|c|c|}
\hline Name & $\beta$-aryl ether & Resinol & Phenylcoumaran & Biphenyl + Dibenzodioxocin & Spirodienone & Diaryl ether \\
\hline Structure & & & & a & & \\
\hline Inter-unit linkage & $\beta-\mathrm{O}-4$ & $(\beta-\beta)+(\gamma-\mathrm{O}-\alpha)$ & $(\beta-5)+(\alpha-O-4)$ & $\begin{array}{l}5-5^{\mathrm{a}} \\
(5-5)+(\alpha-\mathrm{O}-4)+(\beta-\mathrm{O}-4)^{\mathrm{b}}\end{array}$ & $\beta-1+(\alpha-\mathrm{O}-\alpha)$ & $4-\mathrm{O}-5$ \\
\hline Softwood (\%) & $45-50$ & $2-6$ & $9-12$ & $5-7^{\mathrm{b}}$ & $1-9$ & 2 \\
\hline Hardwood (\%) & $60-62$ & $3-16$ & $3-11$ & $<1^{\mathrm{b}}$ & $1-7$ & 2 \\
\hline Grasses $(\%)$ & $74-84$ & $1-7$ & $5-11$ & n.d & n.d & n.d \\
\hline $\mathrm{BDE}(\mathrm{kcal} / \mathrm{mol})$ & $\begin{array}{l}\mathrm{C}_{\beta}-\mathrm{O}-\mathrm{C}_{4^{\prime}} \\
54-72 \\
\mathrm{C}_{\alpha}-\mathrm{C}_{\beta} \\
75-80\end{array}$ & $\begin{array}{l}\mathrm{C}_{\alpha}-\mathrm{O} \\
68 \\
\mathrm{C}_{\alpha}-\mathrm{C}_{\beta} \\
67 \\
\mathrm{C}_{\gamma}-\mathrm{O} \\
79 \\
\mathrm{C}_{\beta}-\mathrm{C}_{\beta} \\
81\end{array}$ & $\begin{array}{l}\mathrm{C}_{\alpha}-\mathrm{O}-\mathrm{C}_{4^{\prime}} \\
50-56 \\
\mathrm{C}_{\alpha}-\mathrm{C}_{\beta} 54-63\end{array}$ & $\begin{array}{l}\mathrm{C}_{5}-\mathrm{C}_{5^{\prime}} \\
115-118\end{array}$ & $\begin{array}{l}C_{\beta}-C_{1^{\prime}} \\
65-69 \\
\text { (for open structure) }\end{array}$ & $\begin{array}{l}\mathrm{C}_{4}-\mathrm{O}-\mathrm{C}_{5} \\
78-83\end{array}$ \\
\hline
\end{tabular}

a-biphenyl, b—dibenzodioxocin

reported that native lignins are relatively easier to depolymerise compared to technical lignins because of the presence of higher proportion of C-O inter-unit linkages [20].

\subsection{Technical Lignins}

Extracting native lignins from lignocellulosic biomass are future targets to achieve, currently available lignins, often called as technical lignins, are the by-products of conventional pulping routes such as kraft, soda, organosolv, hydrolysis and sulphite processes and they are called as kraft lignin, soda lignin, organosolv lignin, hydrolysis lignin and lignosulphonates respectively [35]. Organosolv is a general process where organic solvents such as ethanol, methanol, formic acid, acetic acid, ethylene glycol and tetrahydrofurfuryl alcohol are used to extract lignin [36]. As expected, all these lignins have different structures, often containing different impurities, depending on the pulping and pre-treatment or fractionation processes employed [37]. As mentioned before, native lignin contains a higher proportion of $\mathrm{C}-\mathrm{O}$ inter-unit linkages, however during delignification (lignin fractionation) processes many $\mathrm{C}-\mathrm{C}$ bonds are formed (Fig. 4). Generally, this is due to condensation reactions between compounds cleaved from the native lignin and remaining oligomers chains [38, 39]. In the case of the kraft pulping alkali-promoted condensation reactions take place forming alkali-stable linkages during the pre-treatment of the lignin [40]. Nevertheless, many researches are
Fig. 4 Schematic representation for the formation of $\mathrm{C}-\mathrm{C}$ bond during the delignification process. (Reproduced with permission from reference [39]. Copyright 2017, The Royal Society of Chemistry)
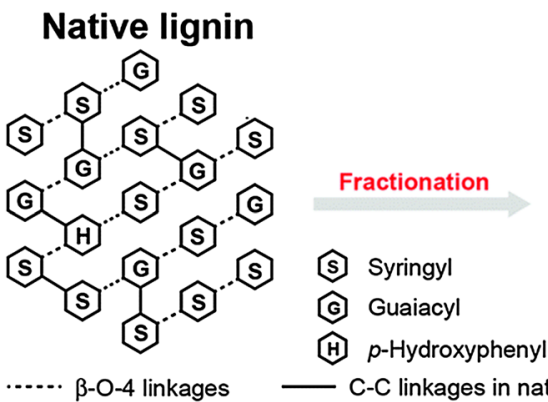

Technical lignin

(H) $p$-Hydroxyphenyl

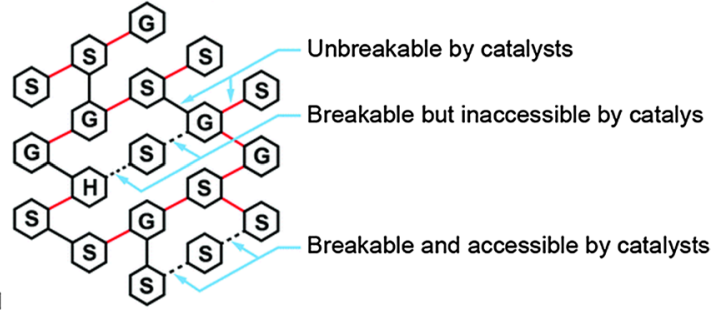

$C-C$ linkages in native lignin

C-C linkages formed during fractionation 
currently investigating the way to minimise this undesired condensation during delignification process by the stabilization of native lignin via addition of biological or chemicals capping agents, solvents, catalytic trapping pathways, and careful tuning of reaction parameters [18, 41]. For example, formaldehyde has been reported to be a good stabiliser, it react with alpha and gamma-hydroxyl groups on the lignin side-chain to form a stable 1,3-dioxane ring structure which prevents further condensation and hence the formation of new C-C linkages [42].

One of the major challenges in the catalytic processing these technical lignins is the presence of these impurities especially sulphur. For this reason, the extraction of technical lignin (delignification process) from biomass are classified into two types: (a) sulphur based processes and (b) nonsulphur based processes (Fig. 5) [37]. The disadvantages of sulphur containing lignin, resulting from sulphur based process, are the characteristic odour and are typically not suitable for catalysts containing noble metals, because sulphur poisons these catalysts. Therefore non-sulphur lignins (organosolv \& soda lignin) are preferred for catalytic valorisation, however sulphur content can be beneficial for some specific catalytic processes where sulphided hydrodeoxygenation catalysts are used [43]. Because of the absence of sulphur, soda lignin and organolv lignins have been used as feedstock for catalytic valorisation reactions increasingly compared to kraft lignin [19]. Besides sulphur content, more physicochemical properties of technical lignins such as molecular weight, polydispersity, moisture, ash content, homogeneity, presence of certain functional groups have to be taken into consideration during feedstock selection for valorisation reactions $[37,44]$.

\subsection{Lignin Valorisation}

Depolymerisation of lignin to smaller molecular weight compounds is a very promising reaction, which can potentially generate value-added products, especially aromatics and functionalised aromatics. These aromatics can be used for the sustainable production of fuels, base chemicals and some high value fine chemicals [45]. Depolymerisation of lignin can be either catalytic or non-catalytic involving the breaking of $\mathrm{C}-\mathrm{O}$ and $\mathrm{C}-\mathrm{C}$ inter-unit linkages present in lignin. These depolymerisation reactions can be oxidative, reductive or redox-neutral. Typically, the oxidative depolymerisation reaction results in aromatic acids, aldehydes and occasionally aliphatic acids via the opening of aromatic ring [16]. The challenge in designing these strategies is to get the desired product(s) in high selectivity by selectively breaking specific inter-unit linkages in order to avoid complex separation processes.

To design strategies for the selective cleavage of interunit linkages, it is a common practice use lignin model compounds, to avoid the complexities such as the presence of impurities and heterogeneous structures involved in using whole lignin $[37,46]$. These model compounds contain specific kind of inter-unit linkages that are present in lignin. A few examples of the model compounds, representing different inter-unit linkages in lignin that are typically used in literature are presented in Fig. 6 1-phenyl-2phenoxyethanol (1), pinoresinol (2), bibenzyl (3), benzofuran (4), diphenylether (5) and biphenyl (6) representing $\beta-\mathrm{O}-4, \beta-\beta, \beta-1, \beta-5,4-\mathrm{O}-5$ and $5-5$ linkages respectively. Lignin model compounds are very useful to study the kinetics and mechanism of these cleavage

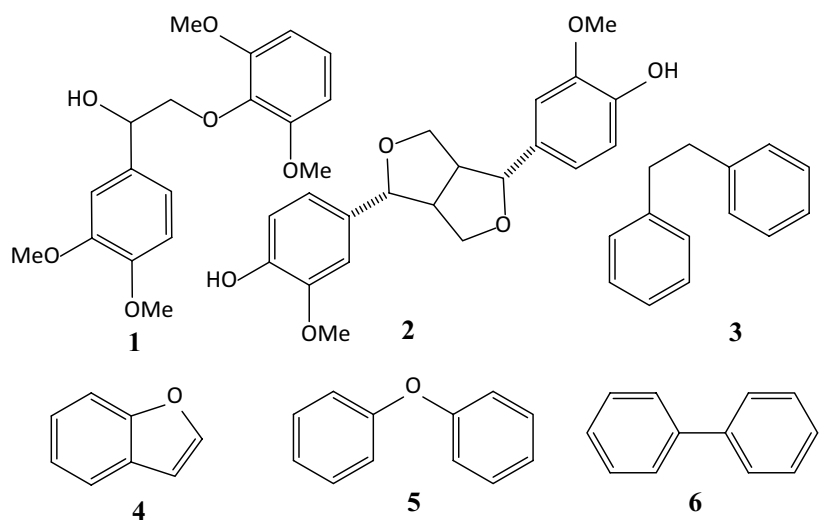

Fig. 6 Structures of some lignin model compounds that contain typical linkages present in lignin: $1(\beta-\mathrm{O}-4), 2(\beta-\beta), 3(\beta-1), 4(\beta-5), 5$ (4-O-5) and $6(5-5)$
Fig. 5 Classification of delignification processes and the resultant technical lignin. The sulphur content in $\%$ is given within brackets for lignins from sulphur based processes. (Adapted from reference [37])

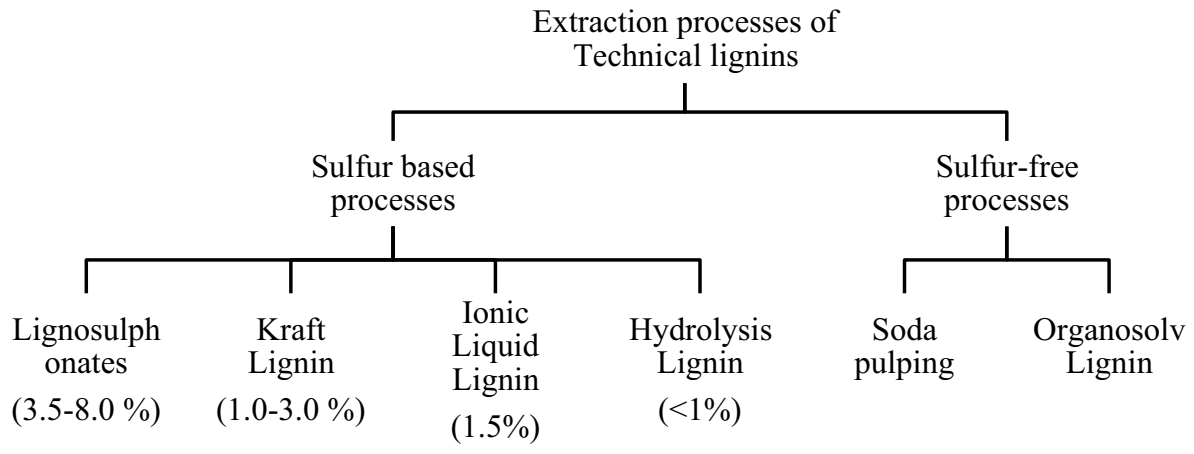

Extraction processes of Technical lignins 
reactions. It is important to highlight that these lignin model compounds (Fig. 6) represent different inter-unit linkages in lignin and at the same time reducing the complexities involved in dealing with compounds with too many functionalities. These less complex model compounds are useful in designing catalysts for the breaking of inter-unit linkages and for in-depth studies on the mechanism of these catalytic reactions. However translating the catalytic results from these model compounds to real lignin is not straight forward as the presence of substituents and other functionalities severely complicate the process. However, these model compounds are a good starting point for catalyt development.

A number of articles have been published on the cleavage of $\mathrm{C}-\mathrm{O}$ inter-unit linkages in model compounds; however reports on the cleavage of $\mathrm{C}-\mathrm{C}$ inter-unit linkages are scarce because of their recalcitrant nature. However, breaking of $\mathrm{C}-\mathrm{C}$ interunit linkages is crucial for the valorisation of technical lignins as they contain more $\mathrm{C}-\mathrm{C}$ linkages than $\mathrm{C}-\mathrm{O}$ linkages. For catalytic systems focussed on the cleavage of $\mathrm{C}-\mathrm{O}$ linkages, readers are encouraged to read some excellent reviews on this subject $[18,47,48]$. Here we present a mini-review on the recently reported strategies for the catalytic cleavage of $\mathrm{C}-\mathrm{C}$ inter-unit linkages in lignin model compounds as well as whole lignin (Fig. 7).

\section{Catalytic C-C Bond Cleavage in Lignin Model Compounds and Technical Lignins}

Catalytic conversion of the components of lignocellulosic biomass to chemicals and fuel components has been the subject of research efforts during the past decade resulting in a $20 \%$ annual increase in the number of publications on this subject [49]. Among these reports, catalytic depolymerisation of lignin has received greater attention recently. In the literature, six major strategies have been reported for the depolymerisation of lignin namely pyrolysis, hydrolysis, oxidation, hydrogenolysis, photocatalytic and enzyme catalysis (biocatalysis) [50]. Some of these routes like pyrolysis are thermal and non-catalytic while others are catalytic. Several catalytic routes including oxidative, reductive, redox neutral, photocatalytic and enzyme catalytic routes have been reported for the cleavage of $\mathrm{C}-\mathrm{O}$ linkages, typically $\beta-\mathrm{O}-4$ inter-unit linkage in lignin model compounds (Compound 1, Fig. 6) [51]. However, in most cases, during these catalytic depolymerisation reactions $\mathrm{C}-\mathrm{C}$ linkages are not broken [52]. In the literature, most of the reported $\mathrm{C}-\mathrm{C}$ bond cleavages are the breaking of $\mathrm{C}_{\alpha}-\mathrm{C}_{\beta}$ and some examples of $\mathrm{C}_{\mathrm{Ph}}-\mathrm{C}_{\alpha}$ bonds in the $\beta-\mathrm{O}-4$ model compound 7 and in some other cases, breaking of the $\mathrm{C}_{\beta}-1$ bond of the lignin model 8 (Fig. 8). However examples on the breaking of $\beta-\beta$ [53], $\beta-5$ [54] and 5-5' [55] linkages are scarce or not known in the literature. In general, these lignin model compounds, with different functional groups $\left(\mathrm{OH}\right.$ or $\mathrm{OCH}_{3}$ or $\left.\mathrm{OC}_{2} \mathrm{H}_{5}\right)$
Fig. 7 Schematic representation of the motivation and the subtopics of this review

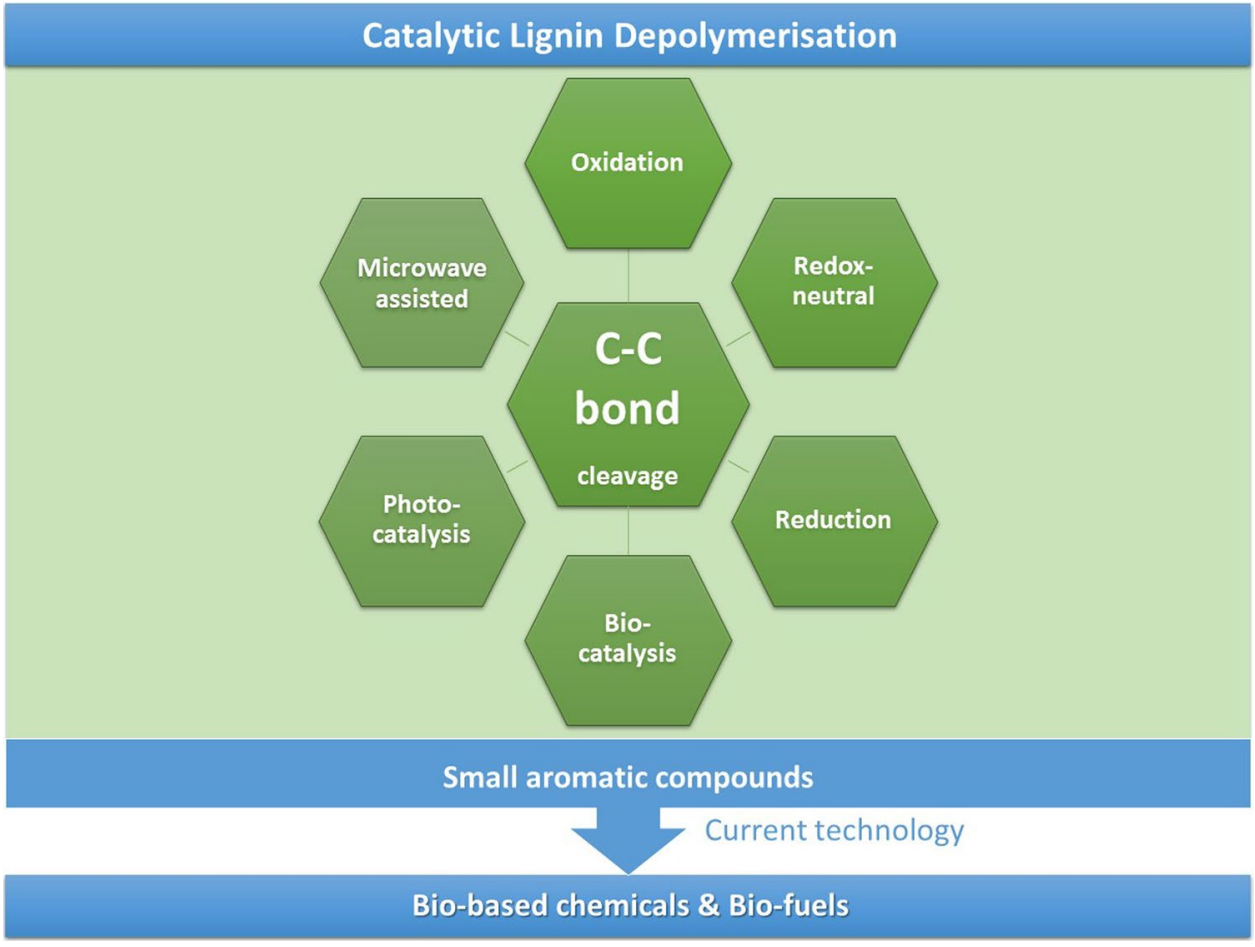


<smiles>[X]c1cc(C(C)OC(C)C([Al])Oc2ccccc2OC)cc([X])c1[X]</smiles>

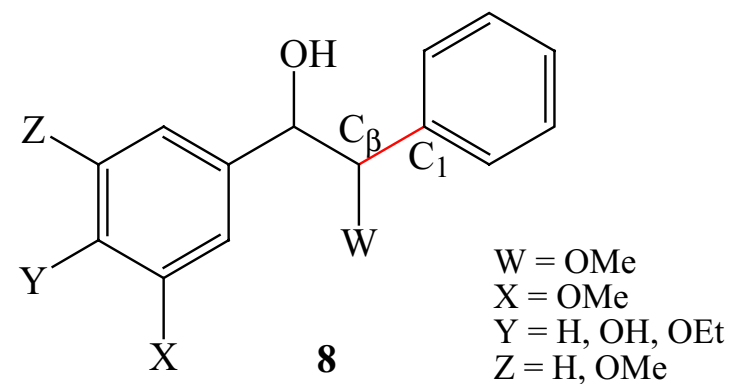

Fig. 8 Commonly used lignin model compounds containing $\beta-\mathrm{O}-4$ linkage (methoxylated phenolic/non-phenolic dimer ( $\beta$-aryl ether), 7) and $\beta-1$ linkage (bibenzyl dimer, 8). Other linkages including $\mathrm{C}-\mathrm{C}$ linkages that can potentially break in these compounds are labelled

at different positions on the aromatic rings, are used as substrates (substrates $7 \& 8$ in Fig. 8), which are derivatives of model compounds $\mathbf{1}$ and $\mathbf{3}$ respectively (Fig. 6).

Through theoretical BDE calculation, Huang et al. proposed the cleavage of $\mathrm{C}_{\alpha}-\mathrm{C}_{\beta}$ linkage in lignin model compound 7 during its high temperature pyrolysis [29]. Here the authors describe the catalytic depolymerisation reaction where $\mathrm{Co}, \mathrm{Cu}, \mathrm{Fe}, \mathrm{Pd}, \mathrm{V}$ and $\mathrm{Ru}$ based metal complexes (some examples are given in Fig. 9) have been reported as active homogeneous catalysts for the cleavage of $\mathrm{C}-\mathrm{C}$ bonds in some model compounds and in technical lignins. Besides homogeneous catalysts, supported metal catalysts, such as monometallic $\mathrm{Pd}, \mathrm{Pt}, \mathrm{Rh}$, or $\mathrm{Ru}$ supported on carbon have also been reported as heterogeneous catalysts for the hydrogenolysis of lignin model compounds in supercritical water with some evidence for $\mathrm{C}-\mathrm{C}$ bond cleavage. Other heterogeneous catalytic systems such as $\mathrm{CoMo} / \mathrm{Al}_{2} \mathrm{O}_{3}$ catalyst, used

Fig. 9 Structures of some of the catalyst used for the oxidative $\mathrm{C}-\mathrm{C}$ bond cleavage as described above in hydrodeoxygenation processes, and $\mathrm{Pt} / \mathrm{Al}_{2} \mathrm{O}_{3}$ employed for aqueous-phase reforming of lignin, are also able to achieve the desired $\mathrm{C}-\mathrm{C}$ bond cleavage. Specific examples of these homogeneous and heterogeneous catalysts are discussed in detail in the next sections.

For clarity, this catalytic $\mathrm{C}-\mathrm{C}$ cleavage section has been sub-divided into (a) oxidative, (b) redox-neutral, (c) reductive, (d) microwave mediated and (e) enzyme and photo catalytic cleavage (Fig. 7).

\subsection{Oxidative C-C Bond Cleavage}

Catalytic oxidation is one of the most widely used methods for the breaking of the inter-unit linkages in lignin, especially $\mathrm{C}-\mathrm{C}$ linkages because of the abundance of hydroxyl groups in lignin [54]. Behling et al. has reported an overview on the recent advances in the oxidative depolymerisation of<smiles>CC1(C)CN2C(=O)C3(C)N4C2N(C1=O)C(C)(C)C(=O)N4C(=O)C3(C)C</smiles>

Fe (TAML) Li

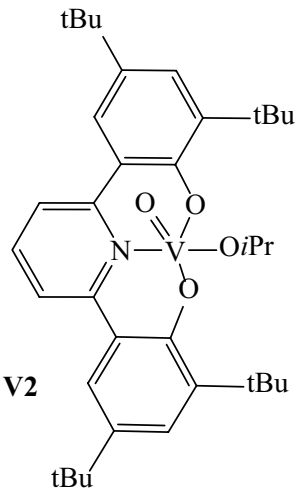<smiles></smiles><smiles>CC1(C)CCCC(C)(C)N1[O]</smiles>

TEMPO

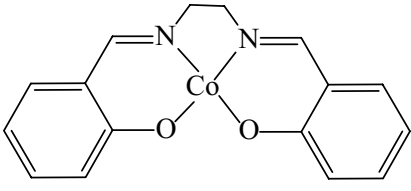

Co (salen) 
lignin including some oxidative $\mathrm{C}-\mathrm{C}$ cleavages [55]. Paper and pulping industries use some of the most advanced oxidative routes for the depolymerisation and eventual removal of traces of lignin present in cellulosic materials [50, 55, 56]. Oxidative depolymerisation of lignins typically result in monomeric oxygenates like carbonyl compounds and carboxylic acids. Hanson et al. reported a general correlation between the oxidative breaking of specific linkage and the resultant product for the model compound 7 represented in Fig. 10 [57]. For example, $\mathrm{C}_{\alpha}-\mathrm{C}_{\beta}$ cleavage results in aromatic aldehydes (or corresponding carboxylic acid), while the $\mathrm{C}_{\alpha}-\mathrm{H}$ cleavage yields corresponding ketones, the breaking of $\mathrm{C}_{\beta}-\mathrm{O}$ bond yields ketones and finally the $\mathrm{C}_{\mathrm{Ph}}-\mathrm{C}_{\alpha}$ cleavage results in acrolein and quinone derivatives [58]. This correlation is useful to rationally design catalytic systems for the targeted cleavage of specific bonds to get specific compound in high yield.

Crestini et al. reported a catalytic, chlorine-free, oxidative cleavage of inter-unit linkages in an array of monomeric and dimeric, phenolic and non-phenolic lignin model compounds using a homogeneous methyltrioxorhenium(VII) $\left(\mathrm{MeReO}_{3}\right)$ (MTO) catalyst and $\mathrm{H}_{2} \mathrm{O}_{2}$ as the oxidant [59]. To study the $\mathrm{C}-\mathrm{C}$ bond cleavage, they used different substituted lignin model compounds having $\beta-\mathrm{O}-4$ units 9 and diphenylmethane units $\mathbf{1 0}$ as substrates (Fig. 11). The model compound $\mathbf{9}$, used in this study, is a highly functionalised version of the simple model compound 1 (Fig. 6). During the catalytic reaction using phenolic model compound $\mathbf{9}$, (substrate-1 in Fig. 11) $>98 \%$ of the substrate was converted to products. The products mixture includes carboxylic acid on the $\mathrm{C}_{\alpha}$ position (4-hydroxy-3-methoxybenzoicacid), carbonyl group on the $\mathrm{C}_{\beta}$ position (hydroxyl-ketone), 2,6-dimethoxyphenol and muconolactone. Among these products, 4-hydroxy3-methoxy benzoic acid was formed by the cleavage of $\mathrm{C}_{\alpha}-\mathrm{C}_{\beta}$ bond; however, the yield of this product was only 16\%. Similarly, when substrates 2 and 3 (Fig. 11) were oxidised, evidence for the cleavage of the $\mathrm{C}_{\alpha}-\mathrm{C}_{\beta}$ bond was also observed [59]. The $\mathrm{C}_{\alpha}-\mathrm{C}_{1}$ linkage present in $\mathbf{1 0}$ is not
Fig. 10 Potential bond breakage pathways and possible products during the catalytic oxidation of lignin model compound 7. (Adapted from reference [58])

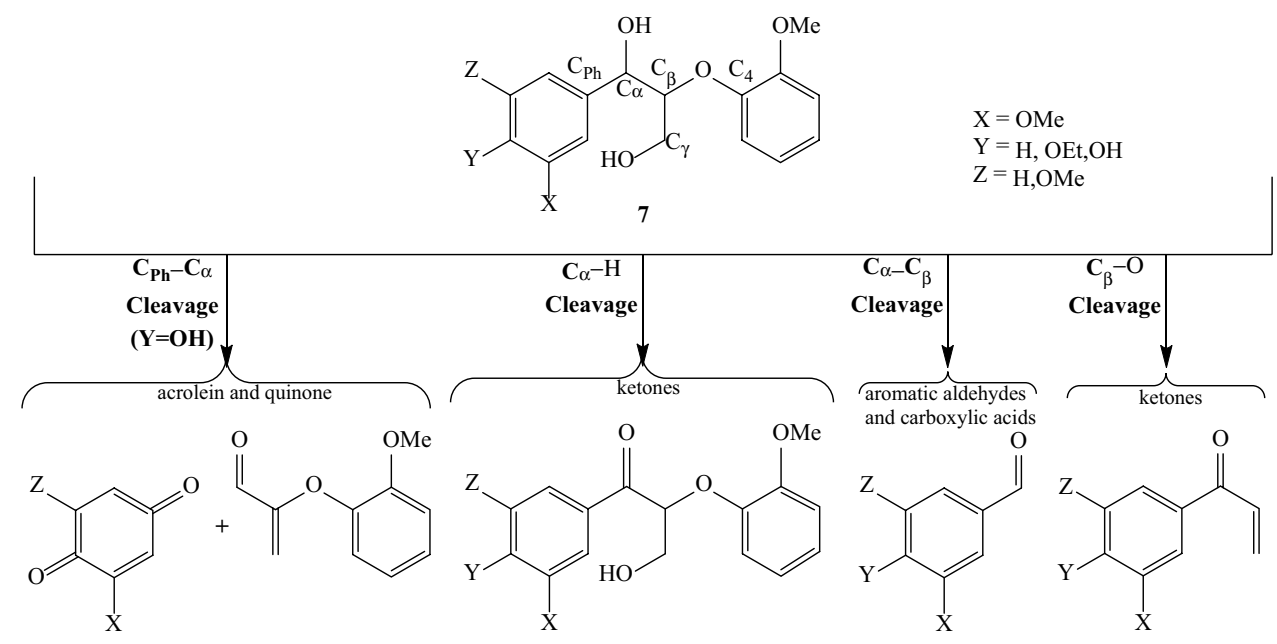

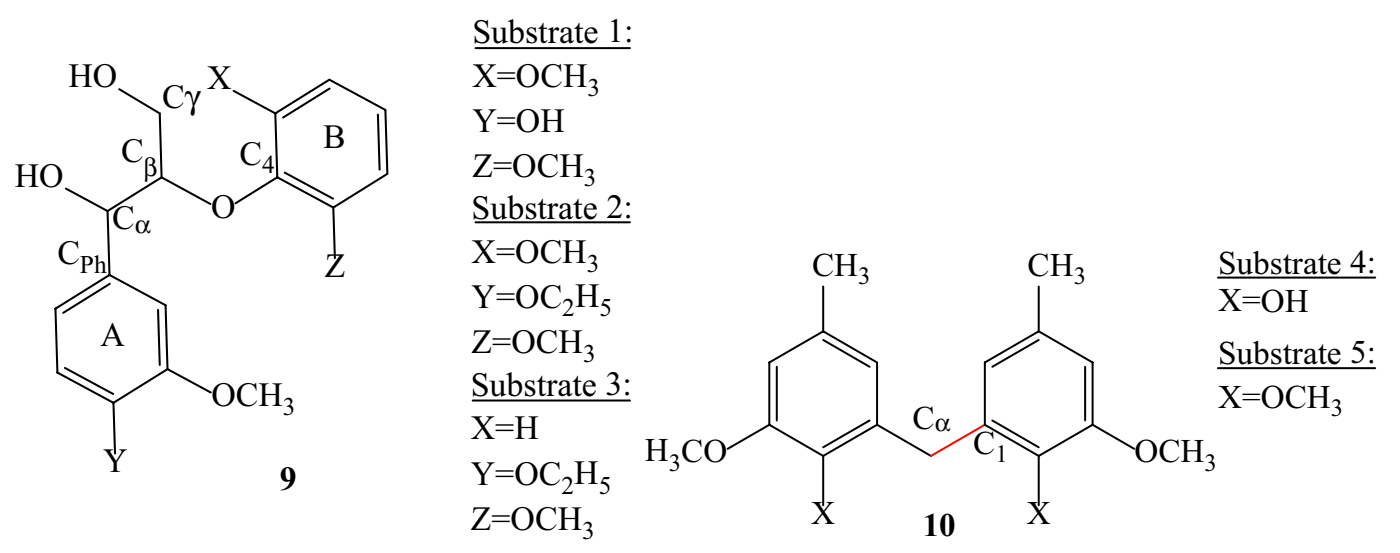

Fig. 11 Phenolic and non-phenolic lignin model compounds with $\beta-\mathrm{O}-4$ units (9) and diphenylmethane units (10) models for substrates $1-5$. (Adapted from reference [59]) 
found in native lignins, however it is formed because of the condensation reactions during the delignification processes, hence it is prevalent in technical lignins [60]. In an effort to break this $\mathrm{C}_{\alpha}-\mathrm{C}_{1}$ linkage, two versions of model compound 10 was oxidised using MTO and $\mathrm{H}_{2} \mathrm{O}_{2}$. For substrate 4 (phenolic model compound in Fig. 11) higher proportion of $\mathrm{C}_{\alpha}-\mathrm{C}_{1}$ cleavage was observed resulting in aromatic carboxylic acids. For the substrate 5 (non-phenolic model compound in Fig. 11) only trace amount of $\mathrm{C}_{\alpha}-\mathrm{C}_{1}$ cleavage was observed. They have concluded that $\mathrm{C}_{\alpha}-\mathrm{C}_{1}$ cleavage is easier in phenolic model compounds, compared to non-phenolic compounds.

Encouraged by these results, Crestini et al. depolymerised technical lignins such as hydrolytic sugar cane lignin (SCL), red spruce kraft lignin (RSL) and hardwood organosolvent lignin (OSL) using MTO and $\mathrm{H}_{2} \mathrm{O}_{2}$ [59]. This catalytic oxidation reaction resulted in a decrease in the content of aliphatic OH groups $(43,14$ and $67 \%$ reduction in SCL, OSL and RSL, respectively) and resulting in the formation of more soluble lignin fragments and higher yields monomeric carboxylic acids. Because of this additional $\mathrm{C}-\mathrm{C}$ cleavage for this catalytic system, it is effective for the depolymerisation of complex technical lignins.

Hanson et al. reported the cleavage of $\mathrm{C}_{\mathrm{Ph}}-\mathrm{C}_{\alpha}, \mathrm{C}_{\alpha}-\mathrm{C}_{\beta}$ and $\beta-1$ inter-unit linkages during the aerobic oxidation of different lignin model compounds 7 and $\mathbf{8}$ (Fig. 8) using different vanadium metal complexes [61, 62]. During the aerobic oxidation of derivatives of model compound $\mathbf{8}$ with $\beta-1$ linkage using $(\mathrm{HQ})_{2} \mathrm{~V}^{\mathrm{V}}(\mathrm{O})\left(\mathrm{O}^{i} \mathrm{Pr}\right)(\mathrm{HQ}=8$-oxyquinolinate) catalyst, they observed substantial $\mathrm{C}_{\mathrm{Ph}}-\mathrm{C}_{\alpha}$ and $\beta-1$ cleavage [61]. Again, phenolic model compounds resulted in substantially higher $\mathrm{C}-\mathrm{C}$ cleavage compared to non-phenolic model compounds and the solvents altered the product distribution. In DMSO solvent benzaldehyde and methanol were the major products, while in pyridine solvent the main products obtained were benzoic acid and methyl benzoate (Fig. 12) [61].

More recently, Ma et al. reported the selective oxidative $\mathrm{C}-\mathrm{C}$ cleavage in model 1 using $\mathrm{VO}(\mathrm{acac})_{2}$ catalyst with molecular oxygen as the oxidant. They further show the effect of solvents on the selectivity with acetic acid being the most desired solvent for $\mathrm{C}-\mathrm{C}$ cleavage [63]. Amadio et al. reported the oxidative cleavage of model compound 7 (Fig. 6, phenolic $\mathrm{X}, \mathrm{Z}=\mathrm{OCH}_{3}, \mathrm{Y}=\mathrm{OH}$ ) using V3 in Fig. 9, where they have found the effect of solvent on the selectivity of $\mathrm{C}_{\mathrm{Ph}}-\mathrm{C}_{\alpha}$ cleavage. The yield of the products as a result of the breaking of $\mathrm{C}_{\mathrm{Ph}}-\mathrm{C}_{\alpha}$ bond follows the order ethylacetate $>2$-methyl THF $>$ pyridine $>$ THF. When non-phenolic version of the model compound $7(\mathrm{X}=\mathrm{H}, \mathrm{Z}=\mathrm{MeO}$, $\mathrm{Y}=\mathrm{EtO}$ ) was used, $\mathrm{C}-\mathrm{C}$ cleavage was not observed at all [58].

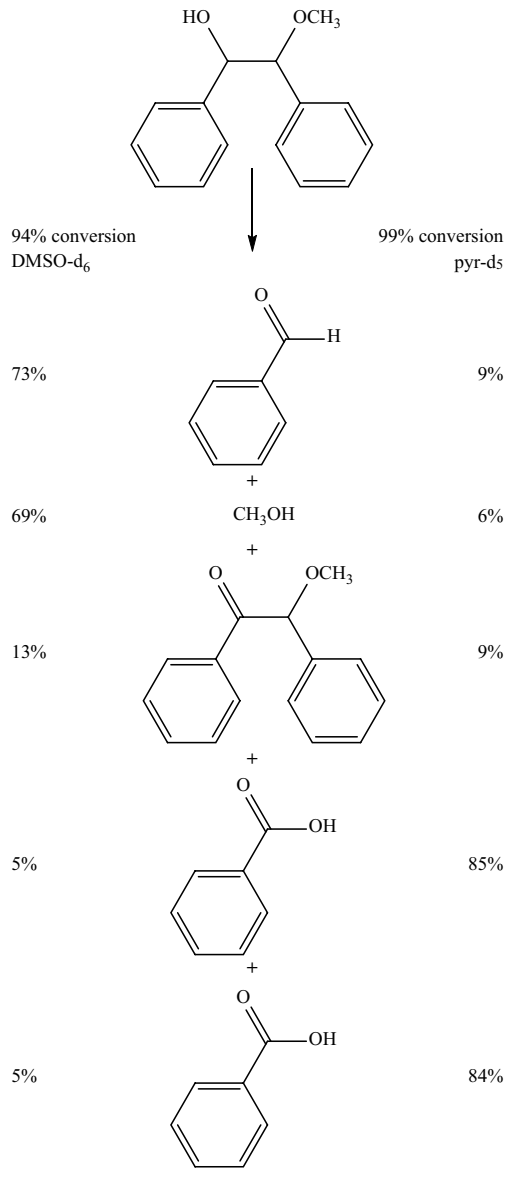

Fig. 12 Effect of solvent on products distribution during the oxidative cleavage of 8 using (dipic) $\mathrm{V}^{\mathrm{IV}}(\mathrm{O})(\mathrm{DMSO})_{2}$ catalyst in DMSO- $\mathrm{d}_{6}$ (left hand side) and Pyridine- $\mathrm{d}_{5}$ (right hand side). (Adapted from reference [61])

\subsection{TEMPO Mediated Oxidative C-C Cleavage}

TEMPO (2,2,6,6-tetramethyl-1-piperidin-1-yl-oxyl in Fig. 9) is used as it is or in combination with metal catalysts for the breaking of inter-unit linkages in lignin. Sedai and Baker reported an effective combined catalytic system containing $\mathrm{CuCl}$ and TEMPO for the oxidation of 1,2-diphenyl2-methoxyethanol (model $8, \mathrm{~W}=\mathrm{OCH}_{3}$, Fig. 8), having $\beta-1$ linkage, using $\mathrm{O}_{2}$ as the oxidant [64]. After $48 \mathrm{~h}$ reaction at $100{ }^{\circ} \mathrm{C}$, they achieved more than $80 \%$ of $\beta-1$ cleavage. However, under similar condition, when (dipicolinate) $\mathrm{V}^{\mathrm{V}}(\mathrm{O})$ $\left(\mathrm{O}^{\mathrm{i}} \mathrm{Pr}\right) \mathrm{V1}$ (Fig. 9) was used as catalyst, the oxidation of secondary alcohol to ketone was followed by $\beta-1$ cleavage in a two step process. However when the intermediate ketone was oxidized by V1, $>90 \%$ of cleavage was observed. The $\mathrm{CuCl}+\mathrm{TEMPO}$ catalytic system is more effective and better than the vanadium catalyst in breaking the $\beta-1$ bond in one step. The same group reported $\mathrm{Cu}(\mathrm{OTf}) / 2,6$-lutidine/ TEMPO catalyst system for the aerobic oxidation of model compound 8 having $\beta-1$ linkage [65]. In comparison to 
vanadium complexes, generally this $\mathrm{Cu}$ catalyst is superior in breaking $\mathrm{C}-\mathrm{C}$ linkages for non-phenolic models $[65,66]$. For phenolic $\beta-1$ model compounds, catalytic amounts of TEMPO were not effective in breaking any $\mathrm{C}-\mathrm{C}$ linkages, however when stoichiometric amounts of TEMPO were used substantial amount of $\mathrm{C}_{\mathrm{Ph}}-\mathrm{C}_{\alpha}$ cleavage was observed [65]. When non-phenolic $\beta-1$ model compounds were tested, even with catalytic amounts of TEMPO substantial amount of $\mathrm{C}_{\alpha}-\mathrm{C}_{\beta}$ bond is broken. From these results we can conclude that for effective cleavage of $\mathrm{C}-\mathrm{C}$ bonds, $\mathrm{CuOTf}+\mathrm{TEMPO}$ (stoichiometric) system is more suitable for phenolic model compounds, whereas catalytic amount CuOTf + TEMPO is preferred for non-phenolic model compounds. When a $1: 1$ mixture of non-phenolic $\beta-1$ and $\beta-\mathrm{O}-4$ model compounds ( $\mathbf{7}$ and $\mathbf{8}$ ) was used for the oxidation reaction using this catalytic system, substantial amount of $\mathrm{C}-\mathrm{C}$ cleavage was observed and $\beta-1$ model compound got converted more readily compared to the $\beta-\mathrm{O}-4$ model compound [65]. Rahimi et al. used catalytic amount of 4-acetamido TEMPO, without any metal, for the oxidation of $\beta-\mathrm{O}-4$ model compound 9 using $\mathrm{O}_{2}$ (Fig. 13). In this reaction, $\mathrm{C}_{\alpha}-\mathrm{C}_{\beta}$ cleavage has been clearly observed. This oxidation methodology has been extended to the depolymerisation of real lignin (Aspen lignin). Through detailed analysis of the product mixture, they propose $\mathrm{C}-\mathrm{C}$ inter-unit cleavage [67].

Díaz-Urrutia et al. compared the catalytic activities of a few vanadium complexes for the oxidative depolymerisation of organosolv lignin and studied the mechanism of the catalytic oxidative cleavage using model compounds. Among all the tested catalysts, only bis(8-oxyquinoline) oxovanadium (V3) (Fig. 9) resulted in C-C cleavage under basic condition. However, under their reaction conditions, CuOTf + TEMPO and TEMPO did not result in C-C cleavage $[68,69]$. Another interesting method for the cleavage of $\mathrm{C}_{\alpha}-\mathrm{C}_{\beta}$ linkage was reported by Patil et al. [70, 71]. Using simple model compounds, in the first step they have oxidised the $\mathrm{OH}$ group in $\mathrm{C}_{\alpha}$ in $\beta-\mathrm{O}-4$ model compound to form ketone using TEMPO/O${ }_{2}$ system. In the second step they converted the ketone to ester using Baeyer-Villiger oxidation (i.e. introducing $\mathrm{O}$ in between $\mathrm{C}_{\alpha}$ and $\mathrm{C}_{\beta}$ ), which is then hydrolysed in situ to form carboxylic acid, aldehyde and phenol (Fig. 14). Though this indirect method of breaking $\mathrm{C}_{\alpha}-\mathrm{C}_{\beta}$ is interesting, it will be less applicable for the depolymerisation of pure lignin [70].

Another two step strategy was proposed by Wang et al. for the cleavage of $\mathrm{C}_{\alpha}-\mathrm{C}_{\beta}$ bond in $\beta-\mathrm{O}-4$ lignin model compound 1 (Fig. 6). In the first step, the secondary $\mathrm{OH}$ group is oxidised to ketone using $\mathrm{VOSO}_{4} /$ TEMPO catalyst and $\mathrm{O}_{2}$ as oxidant. In the second step, the ketone is converted to monomeric phenols and carboxylic acids through the cleavage of $\mathrm{C}_{\alpha}-\mathrm{C}_{\beta}$ bond using $\mathrm{Cu} / 1,10$-phenanthroline catalyst and $\mathrm{O}_{2}$ as oxidant [72]. The bond energy of the $\mathrm{C}_{\alpha}-\mathrm{C}_{\beta}$ bond decreases from $307.7 \mathrm{~kJ} \mathrm{~mol}^{-1}$ for the alcohol to $205.5 \mathrm{~kJ} \mathrm{~mol}^{-1}$ for the ketone, making the ketone an easier substrate for $\mathrm{C}-\mathrm{C}$ cleavage [72]. More recently, the same group developed $\mathrm{Cu}(\mathrm{OAc})_{2} / \mathrm{BF}_{3} \cdot \mathrm{OEt}_{2}$ catalyst for the cleavage of $\mathrm{C}_{\alpha}-\mathrm{C}_{\beta}$ bond in $\beta-\mathrm{O}-4$ model compound $\mathbf{1}$ to produce esters and phenols [73]. Napoly et al. reported Fe (TAML) Li (Fe tetraamido macrocyclic complex) catalyst for the oxidative cleavage of $\mathrm{C}_{\alpha}-\mathrm{C}_{\beta}$ bond in $\beta-\mathrm{O}-4$ model compound $\mathbf{1}$ using (diacetoxyiodo) benzene (DAIB) as the oxidant at $25^{\circ} \mathrm{C}$ (Fig. 15) [74].

They futher report that by increasing the water content in the reaction mixture from $5 \%$ to a $20 \%$ the extent of $\mathrm{C}_{\alpha}-\mathrm{C}_{\beta}$ bond cleavage increased from 45 to $95 \%$. Though the exact role of water in increasing the selectivity of $\mathrm{C}_{\alpha}-\mathrm{C}_{\beta}$ bond cleavage is not clearly understood. They have extended this methodology for the cleavage of $\beta-1$ linkage as well in a lignin model compound similar to 8 [74].

Luo et al. developed a transition-metal free protocol for the selective oxidative $\mathrm{C}-\mathrm{C}$ cleavage in lignin model compounds with sodium persulfate as the oxidant [75]. They tested this system for the oxidative cleavage of different inter-unit linkages in many model compounds. Relevant to this review, using sodium persulfate, Luo et al. were able to
Fig. 13 Schematic representation of the chemoselective oxidation of $\beta-\mathrm{O}-4$ model compound (9) using TEMPO and $\mathrm{O}_{2}$. (Adapted from reference [67])

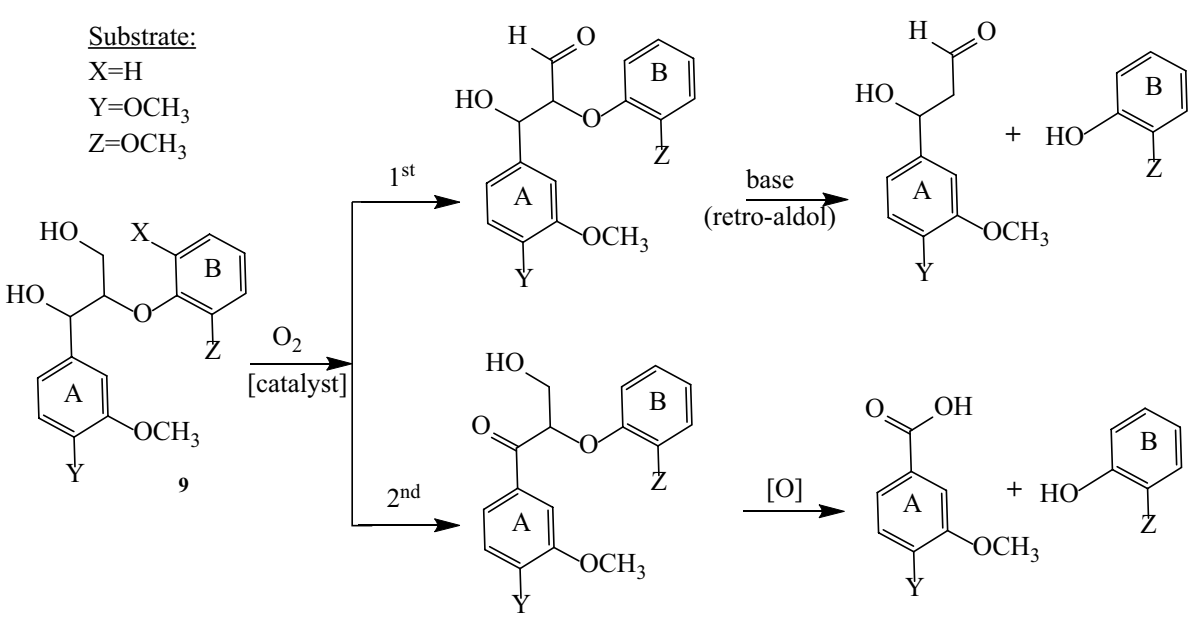


break $\beta-1$ linkage in model compound $\mathbf{3}$ into benzaldehydes in fairly good yields (ca. 60\%). However, they could not translate this methodology for the oxidative depolymerisation of real lignins because of their poor solubility. Cobal salen [Co(salen)] complexes have also been used as homogeneous catalysts for the oxidative cleavage of phenolic and non-phenolic phenylcoumaranes (lignin model compound $4)$, resulting in the cleavage of $\beta-5^{\prime}$ inter-unit linkages to form benzoquinone derivatives, alkylphenyl ketones, benzoic acid derivatives and densely functionalized phenoxyacrylaldehydes. Some quantities of benzofuran (with $\beta-5$ 'intact) has also been found [76]. Biannic and Bozell used Co-Salen complexes for the selective cleavage of the $\mathrm{C}_{\mathrm{Ph}}-\mathrm{C}_{\alpha}$ bond cleavage in $\beta-\mathrm{O}-4$ model compound instead the typically weaker $\beta$-aryl ether linkage (C-O linkage) (Fig. 16). This oxidative cleavage reaction was performed at a milder reaction condition compared to other reported examples. This is one of the few examples where $\mathrm{C}-\mathrm{C}$ bond is broken selectively compared to the $\mathrm{C}-\mathrm{O}$ bond [77].

Mottweiler et al. reported the catalytic oxidative depolymerisation of organosolv beech and kraft lignins using transition-metal-containing hydrotalcites or combinations
Fig. 14 Schematic representation of the two-step method for the breaking of $\mathrm{C} \alpha-\mathrm{C} \beta$ bond via Baeyer-Villiger (BV) oxidation. (Adapted from reference [71])<smiles>[R]c1cc([R5])cc(OC([R3])C(=O)c2ccc([R])c([R])c2)c1</smiles><smiles>COc1ccc(C(O)COc2cccc(C)c2OCC(O)c2ccc(OC)c(OC)c2)cc1OC</smiles><smiles></smiles><smiles>COc1ccc(C=O)cc1O</smiles>

Fig. $15 \mathrm{C}_{\alpha}-\mathrm{C}_{\beta}$ bond cleavage in $\beta-\mathrm{O}-4$ model compound 1 using $\mathrm{Fe}$ (TAML) Li as catalyst and DAIB as the oxidant at $25^{\circ} \mathrm{C}$ Adapted from reference [74]

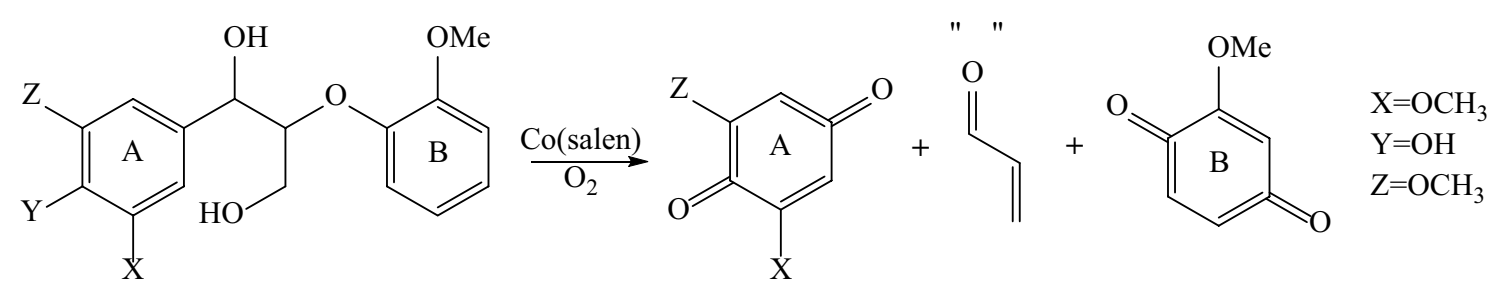

Fig. 16 Cobalt salen catalysed selective oxidative cleavage of $\mathrm{C}_{\mathrm{Ph}}-\mathrm{C}_{\alpha}$ linkage in $\beta-\mathrm{O}-4$ model compound to form benzoquinones. (Adapted from reference [77]) 
of vanadium and copper species using $\mathrm{V}(\mathrm{acac})_{3}$ and $\mathrm{Cu}\left(\mathrm{NO}_{3}\right)_{2} \cdot 3 \mathrm{H}_{2} \mathrm{O}$ as catalysts using $\mathrm{O}_{2}$ [78]. Significant reduction in the molecular weight was observed due to the effective cleavage of $\beta-\mathrm{O}-4$ and other inter-unit linkages. The structure of the modified (depolymerised) lignin post reaction could not be fully understood by NMR, however, based on the resinol structure, they have confirmed that the cleavage of $\beta-\beta$ inter-unit linkage. This is again one of the very few examples where $\beta-\beta$ inter-unit linkage is broken.

\subsection{Redox-Neutral C-C Bond Cleavage}

In the case of $\mathrm{Ru}$, specially Ruthenimun-triphos-based complexes such as $\mathrm{Ru}(\mathrm{H})_{2}(\mathrm{CO})\left(\mathrm{PPh}_{3}\right)$ (xantphos) have been found to be effective in breaking the $\mathrm{C}-\mathrm{O}$ bond in $\beta-\mathrm{O}-4$ lignin model compound 7 [79]. However, it was not effective in breaking the $\mathrm{C}-\mathrm{C}$ bond until vom Stein et al. reported a two-step redox neutral process for the cleavage of $\mathrm{C}-\mathrm{C}$ linkages in lignin model compound 7 (Fig. 8). This redox neutral process involves a dehydrogenation-initiated retroaldol reaction for the $\mathrm{C}_{\alpha}-\mathrm{C}_{\beta}$ bond clevage in different substituted lignin model compounds containing $\beta-\mathrm{O}-4$ linkage (Fig. 17) [80].

\subsection{Reductive C-C Bond Cleavage}

Another catalytic route for the cleavage of $\mathrm{C}-\mathrm{C}$ interunit linkage in lignin model compounds is the reductive pathway. Reports on the oxidative cleavage of lignin model compounds are dominated by homogeneous catalysts, whereas for the reductive cleavage of $\mathrm{C}-\mathrm{C}$ bonds (hydrogenolysis) heterogeneous catalysts are more commonly used. Surprisingly, the first report on the hydrogenolysis of Aspen lignin over copper-chromium catalyst under relatively harsh conditions (220 atm of $\mathrm{H}_{2}$ pressure at $260{ }^{\circ} \mathrm{C}$ ) dates back to 1938 by Harris et al. [81]. Later on, the hydrogenolysis of technical lignins such as organosolv lignin was inspired by the hydrocracking processes developed in the petroleum refineries [82, 83]. During the lignin hydrocracking process mainly $\beta-\mathrm{O}-4$ and $\mathrm{C}_{\mathrm{Ph}}-\mathrm{C}_{\alpha}$ linkages are broken [82]. Oxidative routes are preferred to produce monomeric compounds used in the synthesis of bulk and fine chemicals since the resultant monomeric products are mostly oxygenates. However, hydrogenolysis is preferred to produce alkanes to be used for fuel applications. Huber and Corma also investigated the catalytic cracking of lignin using biomass-derived feedstocks mixed with petroleum-derived feedstocks and triglyceride-based feedstocks as substrate [84]. Catalytic hydrogenolysis of $\mathrm{C}-\mathrm{O}$ linkages are known in the literature, however reports on the hydrogenolysis of $\mathrm{C}-\mathrm{C}$ linkages in lignin model compounds are not common.

The catalytic hydrodeoxygenation (HDO) process is an interesting route to produce biofuels from biomass feedstock by removing oxygen. Jongerius et al. reported the HDO of lignin model compounds (derivatives of models $\mathbf{4 ,} \mathbf{6}$ and 7) using $\mathrm{CoMo} / \mathrm{Al}_{2} \mathrm{O}_{3}$ catalyst. During this HDO reaction, they report the breaking of $\mathrm{C}-\mathrm{C}(\beta-5)$ linkage along with the breaking of $\mathrm{C}-\mathrm{O}(\beta-\mathrm{O}-4)$ linkage. However the $5-5^{\prime}$ linkage in the phenolic model 6 could not be broken under this condition (Fig. 18) [85].

The same group used $1 \% \mathrm{Pt} / \mathrm{Al}_{2} \mathrm{O}_{3}$ for the aqueousphase reforming (APR) of technical lignin and found many monomeric compounds such as syringol or guiaicol in the products mixture and proposed the cleavage of $5-5$ ' linkage (Fig. 19). Though this has not been confirmed by any studies using model compounds. To our knowledge, this is one of the first reports on the cleavage of $5-5^{\prime}$ linkage in the phenolic lignin model compound $\mathbf{6}$, proved by the formation of methylguaiacol (7\%) and guaiacol (12\%) [86].

Yamaguchi et al. reported the cleavage of $\mathrm{C}-\mathrm{O}$ and $\mathrm{C}-\mathrm{C}$ bonds in $\beta-\mathrm{O}-4$ model compound 7 and $\beta-1$ model compound 3 using many supported metal catalysts $(\mathrm{Pd} / \mathrm{C}, \mathrm{Pt} / \mathrm{C}$, $\mathrm{Rh} / \mathrm{C}$, or $\mathrm{Ru} / \mathrm{C}$ ) in supercritical water without any $\mathrm{H}_{2}$. They report that the $\beta-1$ linkage is broken in supercritical water at $673 \mathrm{~K}$ using $\mathrm{Rh} / \mathrm{C}$ catalyst, forming monomers such as toluene and benzene, which are valuable base chemicals [53].

\subsection{Microwave Assisted C-C Bond Cleavage}

Microwave irradiation is an alternative route that has been reported to be promising for lignin depolymerisation [6]. This process was studied on simple lignin models and on organosolv lignin using different supported metal $(\mathrm{Ni}, \mathrm{Pd}, \mathrm{Pt}$ and $\mathrm{Ru}$ ) nanoparticles on mesoporous Al-SBA-15. A $10 \mathrm{wt} \%$

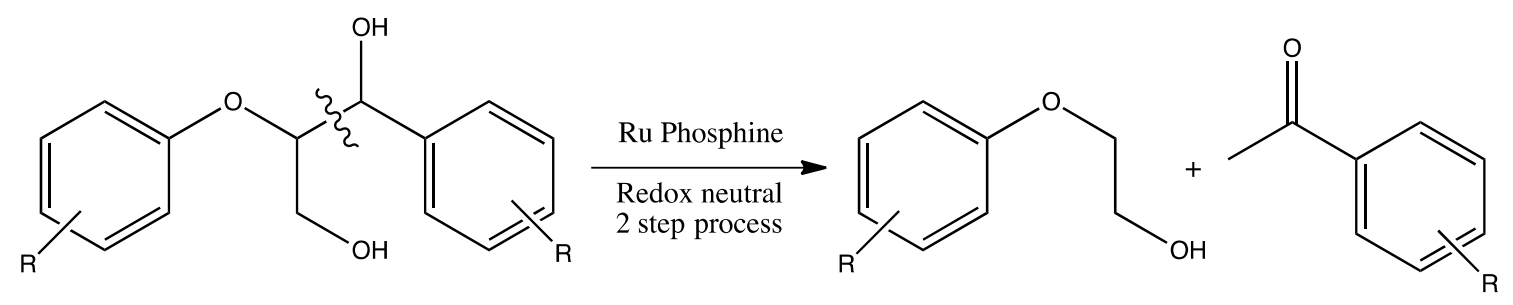

Fig. 17 Schematic representation of the selective cleavage of $\mathrm{C}_{\alpha}-\mathrm{C}_{\beta}$ bond in a $\beta-\mathrm{O}-4$ model compound using a Ru phosphine complex. (Adapted from reference [80]) 
Fig. 18 Catalytic hydrodeoxygenation of a coumaran $(\beta-5$ inter-unit linkage) and $\mathbf{b}$ 2,2'-biphenol (5-5' inter-unit linkage) using $\mathrm{CoMo} / \mathrm{Al}_{2} \mathrm{O}_{3}$ catalyst at $300{ }^{\circ} \mathrm{C}$ and 50 bar $\mathrm{H}_{2}$ pressure for $4 \mathrm{~h}$. (Adapted from reference [85])

A

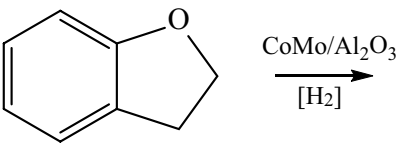

$18 \%$ conversion<smiles>CCc1ccccc1O</smiles>

2-ethylphenol (65\%)<smiles>CCc1ccccc1</smiles>

ethylbenzene (3\%)

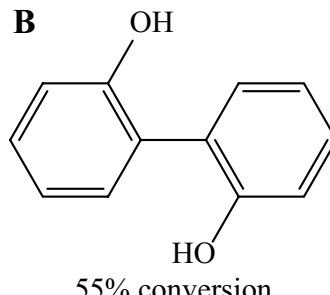

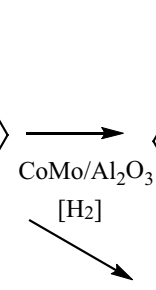<smiles>O=[W]1C=CC=C(c2ccccc2)C1O</smiles>

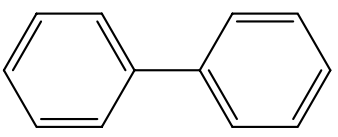

biphenyl (2\%)<smiles></smiles><smiles>C1=CC2OC3C=CC=CC3C2C=C1</smiles>

tetrahydrodibenzofuran (4\%)<smiles>COc1cc(C)cc(-c2cc(C)cc(OC)c2O)c1O</smiles><smiles>COc1cc(C)cc(-c2cc(C)cc(O)c2O)c1O</smiles><smiles>COc1cc(C)cc(-c2cc(C)cc(O)c2O)c1O</smiles>

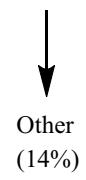<smiles>COc1cc(C)ccc1O</smiles>

Methylguaiacol (7\%)<smiles>COc1ccccc1O</smiles>

Guaiacol (12\%)

Fig. 19 Products obtained from the APR of 6 using $1 \% \mathrm{Pt} / \mathrm{Al}_{2} \mathrm{O}_{3}$. The formation of methylguaiacol and guaiacol confirm the cleavage of 5-5' linkage. (Adapted from reference [86])

nickel supported on mesoporous Al-SBA-15 was found to be the most active catalyst yielding $30 \%$ of bio-oil from organosolv lignin after half an hour of reaction using formic acid as hydrogen donor $[87,88]$. Zhu et al. utilised the microwave assisted cleavage of inter-unit linkages in lignin model compounds using ferric sulphate $\mathrm{Fe}_{2}\left(\mathrm{SO}_{4}\right)_{3}$ and HZSM-5 as catalysts to produce aldehydes, secondary alcohol or ketone compounds [89]. Then, they extended this methodology for the catalytic depolymeristion of organosolv lignin to produce aromatic monomers (vanillin, syringaldehyde, methyl vanillate, and methyl syringate). They further report that these products are formed by the selective cleavage of $\mathrm{C}_{\alpha}-\mathrm{C}_{\beta}$ bond (promoted by the $\mathrm{Fe}^{3+}$ ) over the $\mathrm{C}-\mathrm{O}$ bond (Fig. 20) [90]. Compared to conventional heating, microwave heating resulted in a $48.9 \%$ increase in the cleavage of $\mathrm{C}_{\alpha}-\mathrm{C}_{\beta}$ bonds for Sigma lignin and this increase is more substantial for organosolv lignin (62.3\%) [90]. This microwave assisted cleavage of inter-unit linkages in technical lignin appears to be an interesting approach, however, more work has to be done to further understand why microwave heating is more effective in breaking $\mathrm{C}-\mathrm{C}$ bonds in lignin. 


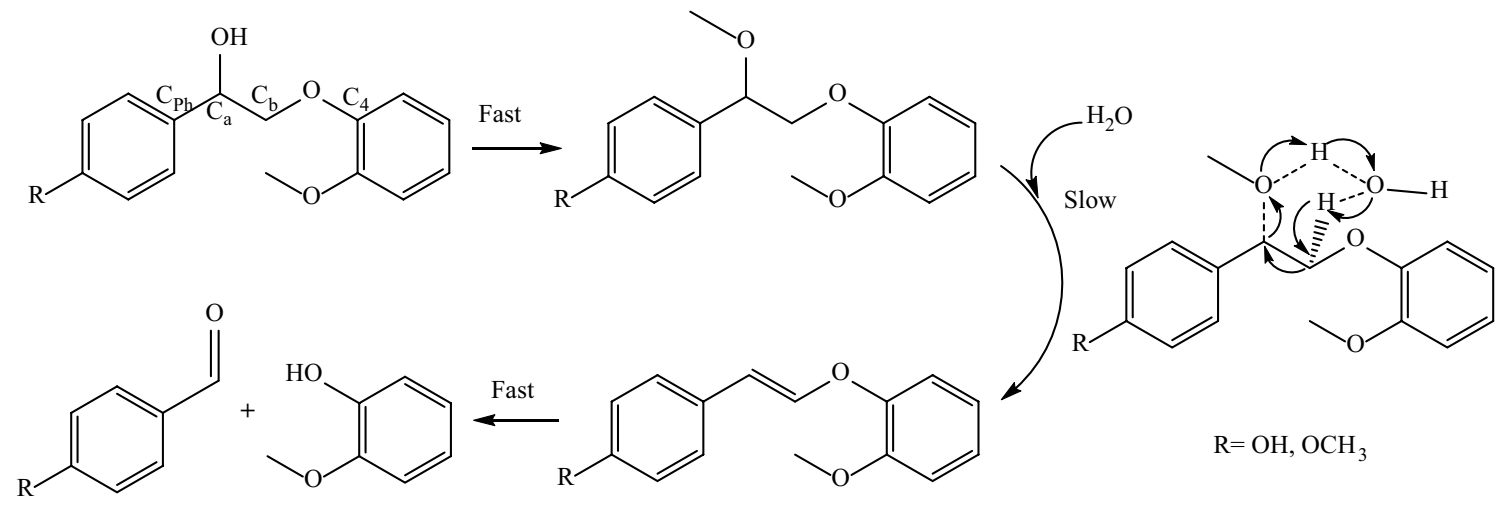

Fig. 20 Decomposition products during the microwave-assisted selective cleavage of the $\mathrm{C}_{\alpha}-\mathrm{C}_{\beta}$ bond in lignin model compound. (Adapted from reference [90])

\subsection{Enzyme Catalysed and Photocatalytic C-C Bond Cleavage}

Biocatalytic valorisation of low molecular weight lignin has been studied extensively and Abdelaziz et al. has reviewed this subject recently [91]. Tien and Kirk reported the first enzymatic degradation of spruce and birch lignins using phanerochaete chrysosporium and $\mathrm{H}_{2} \mathrm{O}_{2}$. In this they have reported the cleavage of $\mathrm{C}-\mathrm{C}$ bonds in lignin model compounds [92]. This report inspired many research groups to work in the area of enzymatic degradation of lignin and lignin model compounds [93]. Through careful mechanistic investigation, Schoemaker et al. proposed a mechanism for this enzyme catalysed oxidative cleavage of $\mathrm{C}_{\alpha}-\mathrm{C}_{\beta}$ bond in $\beta-1$ lignin model compound involving single-electron transfer (SET) between aromatic rings resulting in a cationic radical of the substrate is formed [94, 95]. Inspired by these developments, Shimada et al. developed a tetraphenylporphyrinatoiron (III) chloride complex and tertbutyl hydrogenperoxide system for an unprecedented $\mathrm{C}-\mathrm{C}$ bond cleavage in a non-phenolic $\beta-1$ lignin model dimer $[94,96]$. They used 1,2-bis(4-ethoxy-3-methoxyphenyl) propane1,3-diol, which is a combination of $2 \beta-\mathrm{O}-4$ linkages (model 1) with a $\beta-1$ linkages (model 3) as a model compound for this study. After these reports, enzyme catalysed oxidative depolymerisation has been widely studied, especially using peroxidases [97] and laccases [76]. An example of it is the use of peroxidase pleurotous ostreaus for the depolymerisation of lignosulfonate in the presence of a $\mathrm{H}_{2} \mathrm{O}_{2}$. Here they report the production of 2,6-dimethoxy-1,4-benzoquinone, benzoic acid, butyl phthalate, and bis(2-ethylhexyl) phthalate at ambient conditions [98]. These products are formed by the cleavage of many inter-unit linkages including $\mathrm{C}_{\alpha}-\mathrm{C}_{\beta}$ linkage [88, 98]. Cho et al. combined enzyme catalysis with photocatalysis for a highly regioselective $\mathrm{C}-\mathrm{C}$ bond cleavage in $\beta-1$ and $\beta-\mathrm{O}-4$ model compounds through cationic radicals generated through SET process $[99,100]$. In this report, cation radicals were generated by using SET-sensitized photochemical and $\mathrm{Ce}(\mathrm{IV})$ and lignin peroxidase promoted oxidative processes. Photocatalytic methodologies have been used for the successful C-C bond cleavage recently. Mitchell and Moody reported the successful photocalytic cleavage of $\mathrm{C}-\mathrm{C}$ linkages in a range of 1,2-diols and $\beta-\mathrm{O}-4$ model compounds under visible light (solar) irradiation using 1,4-hydroquinone with a copper supported on aluminum oxyhydroxide catalyst $(\mathrm{Cu} / \mathrm{AlO}(\mathrm{OH}))$ with oxygen as the oxidant [101]. In this system, the catalyst function as the electron transfer mediator (ETM) through the $\mathrm{Cu}(\mathrm{I}) / \mathrm{Cu}(\mathrm{II})$ redox couple.

\section{Concluding Remarks and Future Prospects}

One of the promising strategies, to produce aromatic compounds from sustainable feedstock, is to depolymerise lignin to smaller aromatic compounds. Lignin contains two interunit linkages namely $\mathrm{C}-\mathrm{O}$ and $\mathrm{C}-\mathrm{C}$ linkages and for the complete depolymerisation of ligin, it is important to break these two kinds of linkages effectively. Many catalytic and non-catalytic strategies have been reported for the breaking of $\mathrm{C}-\mathrm{O}$ linkages, however reports on the effective breaking of $\mathrm{C}-\mathrm{C}$ inter-unit linkages are scarce. This is because of the fact that the $\mathrm{C}-\mathrm{C}$ inter-unit linkages are inherently stronger than the $\mathrm{C}-\mathrm{O}$ linkages, hence tougher to break. However, all technical lignins (derived from paper and pulping industries) have higher proportion of $\mathrm{C}-\mathrm{C}$ linkages than $\mathrm{C}-\mathrm{O}$ linkages. Since technical lignins are available in huge quantities, it is important to design strategies to break the $\mathrm{C}-\mathrm{C}$ linkages to achieve complete depolymerisation of technical lignins to smaller aromatic compounds. Here we review the reported strategies on breaking of $\mathrm{C}-\mathrm{C}$ inter-unit linkages in lignin model compounds. Catalytic oxidation is the most widely used method for the cleavage of $\mathrm{C}-\mathrm{C}$ bonds in lignin. However, other strategies such as hydrogenolysis, redox-neutral two step method, microwave assisted cleavage, biocatalytic 
and photochemical routes have also been reported for the breaking of $\mathrm{C}-\mathrm{C}$ bond. Inspite of a number of reports on the breaking of $\mathrm{C}-\mathrm{C}$ bonds, strategies to break typical interunit $\mathrm{C}-\mathrm{C}$ linkages like $\beta-\beta$ and $5-5$ ' have not yet been reported. The aim of this review is to motivate researchers to design new catalytic methologies to break these inter-unit linkages using model compounds. Then, based on the abundance of $\mathrm{C}-\mathrm{O}$ and $\mathrm{C}-\mathrm{C}$ linkages an integrated approach towards the complete depolymerisation of lignin (native or native like and technical) to smaller aromatic compounds should be designed to realise the dream of a green and sustainable society.

Acknowledgements SGM and MS thank Cardiff University for PhD studentship and University Research Fellowship respectively.

Open Access This article is distributed under the terms of the Creative Commons Attribution 4.0 International License (http://creativeco mmons.org/licenses/by/4.0/), which permits unrestricted use, distribution, and reproduction in any medium, provided you give appropriate credit to the original author(s) and the source, provide a link to the Creative Commons license, and indicate if changes were made.

\section{References}

1. Popp J, Lakner Z, Harangi-Rákos M, Fári M (2014) Renew Sustain Energ Rev 32:559-578

2. Miller RG, Sorrell SR (2014) Philos Trans A 372:20130179

3. Tuck CO, Perez E, Horvath IT, Sheldon Ra, Poliakoff M (2012) Science 337:695-699

4. Thompson P (2012) Agriculture 2:339-358

5. Saini JK, Saini R, Tewari L (2015) Biotech 5:337-353

6. Clark JH, Budarin V, Deswarte FEI, Hardy JJE, Kerton FM, Hunt AJ, Luque R, Macquarrie DJ, Milkowski K, Rodriguez A, Samuel O, Tavener SJ, White RJ, Wilson AJ (2006) Green Chem 8:853-860

7. Zakzeski J, Bruijnincx PCA, Jongerius AL, Weckhuysen BM (2010) Chem Rev 110:3552-3599

8. Kubicek CP (2012) Fungi and lignocellulosic biomass. Wiley, Ames,ch1, pp 1-28

9. Kaparaju P, Serrano M, Thomsen AB, Kongjan P, Angelidaki I (2009) Bioresour Technol 100:2562-2568

10. Isikgor FH, Becer CR (2015) Polym Chem 6:4497-4559

11. Plackett D (2011) Biopolymers: new materials for sustainable films and coatings. Wiley, Hoboken

12. Berezina N, Maria S (2014) Bio-based polymers and materials. In: Berezina N, Maria S (eds) Renewable resources for biorefineries, Royal Society of Chemistry, Cambridge, ch1, pp 1-28

13. Cherubini F, Strømman AH (2011) Biofuels Bioprod Bioref 5:548-561

14. Cotana F, Cavalaglio G, Nicolini A, Gelosia M, Coccia V, Petrozzi A, Brinchi L (2014) Energy Proced 45:52-60

15. Cavani F, Albonetti S, Basile F, Gandini A (2016) Chemicals and fuels from bio-based building blocks. Wiley, Hoboken, ch11, p. 758

16. Ragauskas AJ, Beckham GT, Biddy MJ, Chandra R, Chen F, Davis MF, Davison BH, Dixon RA, Gilna P, Keller M, Langan P, Naskar AK, Saddler JN, Tschaplinski TJ, Tuskan
GA, Wyman CE (2014) Science 344:1246843. https://doi. org/10.1126/science. 1246843

17. Calvo-Flores FG, Dobado JA, Isac-García J, Martín-MartíNez FJ (2015) Lignin and lignans as renewable raw materials. Wiley, Hoboken, ch10, pp 313-368

18. Rinaldi R, Jastrzebski R, Clough MT, Ralph J, Kennema M, Bruijnincx PCA, Weckhuysen BM (2016) Angew Chem Int Ed 55:8164-8215

19. Laurichesse S, Avérous L (2014) Prog Polym Sci 39:1266-1290

20. Li C, Zhao X, Wang A, Huber GW, Zhang T (2015) Chem Rev 115:11559-11624

21. Nicholson DJ, Guilford CR, Abiola AB, Bose SK, Francis RC (2015) PEERS Conf 7:1-14

22. Lupoi J, Simmons BA (2015) Renew Sustain Energy Rev 49:871-906

23. Birch S, Fagerstedt KV, Saranpä P (2015) Plants 4:183-195

24. Kline LM, Hayes DG, Womac AR, Labbe N (2010) BioResources 5:1366-1383

25. Lancefield CS, Ojo OS, Tran F, Westwood NJ (2015) Angew Chem Int Edit 54:258-262

26. Kang S, Xiao L, Meng L, Zhang X, Sun R (2012) Int J Mol Sci 13:15209-15226

27. Rencoret J, Marques G, Gutiérrez A, Ibarra D, Li J, Gellerstedt G, Santos JI, Jiménez-Barbero J, Martínez Ángel T, del Río José C (2008) Holzforschung 62:514

28. Windeisen E, Wegener G (2012) Polymer science: a comprehensive reference. Elsevier, Amsterdam, pp 255-265

29. Huang J-b, Wu S-b, Cheng H, Lei M, Liang J-j, Tong H (2015) J Fuel Chem Technol 43:429-436

30. Sakakibara A (1980) Wood Sci Technol 14:89-100

31. Ralph J, Landucci LL (2010) Lignin and lignans: advances in chemistry. CRC Press, Boca Raton, pp 137-244

32. Guerra A, Filpponen I, Lucia LA, Saquing C, Baumberger S, Argyropoulos DS (2006) J Agr Food Chem 54:5939-5947

33. Fasching M, Schröder P, Wollboldt RP, Weber Hedda K, Sixta H (2008) Holzforschung 62:15

34. Renders T, Van den Bosch S, Koelewijn SF, Schutyser W, Sels BF (2017) Energy Environ Sci 10:1551

35. Mansouri N-EE, Salvadó J (2006) Ind Crop Prod 24:8-16

36. Ramírez-wong B, Bello-pérez LA, Montaño B (2014) BioResources 9:1-28

37. Vishtal AG, Kraslawski A (2011) BioResources 6:3547-3568

38. Brandt A, Chen L, Dongen BE, Van T, Welton, Hallett JP (2015) Green Chem 17:5019-5034

39. Shuai L, Saha B (2017) Green Chem 19:3752-3758

40. Chakar FS, Ragauskas AJ (2004) Ind Crop Prod 20:131-141

41. Shuai L, Amiri MT, Luterbacher JS (2016) Curr Opin Green Sustain Chem 2:59-63

42. Boerjan W, Ralph J, Baucher M (2013) Annu Rev Plant Biol 54:519-546

43. Constant S, Wienk HLJ, Frissen AE, Peinder Pd, Boelens R, van Es DS, Grisel RJH, Weckhuysen BM, Huijgen WJJ, Gosselink RJA, Bruijnincx PCA (2016) Green Chem 18:2651-2665

44. Matsushita Y (2015) J Wood Sci 61:230-250

45. Wang H, Tucker M, Ji Y (2013) J Appl Chem 2013:9

46. Parthasarathi R, Romero RA, Redondo A, Gnanakaran S (2011) J Phys Chem Lett 2:2660-2666

47. Dai J, Patti AF, Saito K (2016) Tet Lett 57:4945-4951

48. Xu C, Arancon RAD, Labidi J, Luque R (2014) Chem Soc Rev 43:7485-7500

49. Besson M, Gallezot P, Pinel C (2014) Chem Rev 114:1827-1870

50. Zhu C, Ding W, Shen T, Tang C, Sun C, Xu S, Chen Y, Wu J, Ying H (2015) ChemSusChem 8:1768-1778

51. Bozell JJ, O’Lenick CJ, Warwick S (2011) J Agr Food Chem 59:9232-9242 
52. Chui M, Metzker G, Bernt CM, Tran AT, Burtoloso ACB, Ford PC (2017) ACS Sustain Chem Eng 5:3158-3169

53. Yamaguchi A, Mimura N, Shirai M, Sato O (2017) Sci Rep-UK 7:46172

54. Pandey MP, Kim CS (2011) Chem Eng Technol 34:29-41

55. Behling R, Valange S, Chatel G (2016) Green Chem 18:1839-1854

56. Ma R, Xu Y, Zhang X (2015) ChemSusChem 8:24-51

57. Hanson SK, Wu R, Silks LAP (2012) Angew Chem Int Ed 124:3466-3469

58. Amadio E, Di Lorenzo R, Zonta C, Licini G (2015) Coord Chem Rev 301:147-162

59. Crestini C, Pro P, Neri V, Saladino R (2005) Bioorg Med Chem 13:2569-2578

60. Ahvazi BC, Pageau G, Argyropoulos DS (1998) Can J Chem 76:506-512

61. Hanson SK, Baker RT, Gordon JC, Scott BL, Thorn DL (2010) Inorg Chem 49:5611-5618

62. Hanson SK, Wu R, R. and Silks LAP (2012) Angew Chem Int Ed 7:3466-3469

63. Ma Y, Du Z, Liu J, Xia F, Xu J (2015) Green Chem 17:4968-4973

64. Sedai B, Baker RT (2014) Adv Synth Catal 356:3563-3574

65. Sedai B et al (2013) Aerobic oxidation of $\beta$-1 lignin model compounds with copper and oxovanadium catalysts. ACS Catal 3:3111-3122

66. Sedai B, Díaz-Urrutia C, Baker RT, Wu R, Silks LAP, Hanson SK (2011) ACS Catal 1:794-804

67. Rahimi A, Azarpira A, Kim H, Ralph J, Stahl SS (2013) J Am Chem Soc 135:6415-6418

68. Diaz-Urrutia C, Chen W-C, Crites C-O, Daccache J, Korobkov I, Baker RT (2015) RSC Adv 5:70502-70511

69. Díaz-Urrutia C, Sedai B, Leckett KC, Baker RT, Hanson SK (2016) ACS Sustain Chem Eng 4:6244-6251

70. Patil ND, Yao SG, Meier MS, Mobley JK, Crocker M (2015) Org Biomol Chem 13:3243-3254

71. Patil ND (2014) A Study of Lignin Depolymerization By Selective Cleavage of the $\mathrm{C}_{\alpha}-\mathrm{C}_{\beta}$ Linkages in Lignin Model Compounds via Bayer Villiger Oxidation. PhD thesis submitted to University of Kentuky

72. Wang M, Lu J, Zhang X, Li L, Li H, Luo N, Wang F (2016) ACS Catal 6:6086-6090

73. Wang M, Li LH, Lu JM, Li HJ, Zhang XC, Liu HF, Luo NC, Wang F (2017) Green Chem 19:702-706

74. Napoly F, Jean-Gérard L, Goux-Henry C, Draye M, Andrioletti B (2014) Eur J Org Chem 2014:781-787

75. Luo F-X, Zhou T-G, Li X, Luo Y-L, Shi Z-J (2015) Org Chem Front 2:1066-1070
76. Lange H, Decina S, Crestini C (2013) Eur Polym J 49:1151-1173

77. Biannic B, Bozell JJ (2013) Org Lett 15:2730-2733

78. Mottweiler J, Puche M, Räuber C, Schmidt T, Concepción P, Corma A, Bolm C (2015) ChemSusChem 8:2106-2113

79. Wu A, Patrick BO, Chung E, James BR (2012) Dalton Trans 41:11093-11106

80. vom Stein T, den Hartog T, Buendia J, Stoychev S, Mottweiler J, Bolm C, Klankermayer J, Leitner W (2015) Angew Chem Int Ed 54:5859-5863

81. Harris EE, D'Ianni J, Adkins H (1938) J Am Chem Soc 60:1467-1470

82. Thring RW, Breau J (1996) Fuel 75:795-800

83. Hepditch MM, Thring RW (2000) Can J Chem Eng 78:226-231

84. Huber GW, Corma A (2007) Angew Chem Int Ed 46:7184-7201

85. Jongerius AL, Jastrzebski R, Bruijnincx PCA, Weckhuysen BM (2012) J Catal 285:315-323

86. Zakzeski J, Weckhuysen BM (2011) ChemSusChem 4:369-378

87. Toledano A, Serrano L, Pineda A, Romero AA, Luque R, Labidi J (2014) Appl Catal B 145:43-55

88. Pineda A, Lee AF (2016) Appl Petrochem Res 6:243-256

89. Zhu G, Ouyang X, Yang Y, Ruan T, Qiu X (2016) RSC Adv 6:17880-17887

90. Zhu G, Jin D, Zhao L, Ouyang X, Chen C, Qiu X (2017) Fuel Process. Technol 161:155-161

91. Abdelaziz OY, Brink DP, Prothmann J, Ravi K, Sun M, GarcíaHidalgo J, Sandahl M, Hulteberg CP, Turner C, Lidén G, GorwaGrauslund MF (2016) Biotechnol Adv 34:1318-1346

92. Tien M, Kirk TK (1983) Science 221:661-663

93. Glenn JK, Morgan MA, Mayfield MB, Kuwahara M, Gold MH (1983) Biochem Biophys Res Commun 114:1077-1083

94. Schoemaker HE, Harvey PJ, Bowen RM, Palmer JM (1985) FEBS Lett 183:7-12

95. Harvey PJ, Schoemaker HE, Bowen RM, Palmer JM (1985) FEBS Lett 183:13-16

96. Shimada M, Habe T, Umezawa T, Higuchi T, Okamoto T (1984) Biochem Biophys Res Commun 122:1247-1252

97. Hammel KE, Jensen KA, Mozuch MD, Landucci LL, Tien M, Pease EA (1993) J Biol Chem 268:12274-12281

98. Shin K-S, Lee Y-J (1999) Biotechnol Lett 21:585-588

99. Cho DW, Latham JA, Park HJ, Yoon UC, Langan P, DunawayMariano D, Mariano PS (2011) J Org Chem 76:2840-2852

100. Cho DW, Parthasarathi R, Pimentel AS, Maestas GD, Park HJ, Yoon UC, Dunaway-Mariano D, Gnanakaran S, Langan P, Mariano PS (2010) J Org Chem 75:6549-6562

101. Mitchell LJ, Moody CJ (2014) J Org Chem 79:11091-11100 